\title{
Intracellular labeling and quantification process by magnetic resonance imaging using iron oxide magnetic nanoparticles in rat $\mathrm{C} 6$ glioma cell line
}

\author{
Marcação intracelular e processo de quantificação por imagem por ressonância magnética \\ utilizando nanopartículas magnéticas de óxido de ferro em \\ células da linhagem C6 de glioma de rato
}

\begin{abstract}
Javier Bustamante Mamani ${ }^{1}$, Lorena Favaro Pavon ${ }^{1}$, Liza Aya Mabuchi Miyaki²,Tatiana Tais Sibov ${ }^{1}$, Fabiana Rossan ${ }^{1}$, Paulo Henrique Silveira ${ }^{1}$, Walter Humberto Zavala Cárdenas ${ }^{1}$, Edson Amaro Junior ${ }^{3}$, Lionel Fernel Gamarra ${ }^{1}$
\end{abstract}

\begin{abstract}
Objective: To assess intracellular labeling and quantification by magnetic resonance imaging using iron oxide magnetic nanoparticles coated with biocompatible materials in rat C6 glioma cells in vitro. These methods will provide direction for future trials of tumor induction in vivo as well as possible magnetic hyperthermia applications. Methods: Aminosilane, dextran, polyvinyl alcohol, and starch-coated magnetic nanoparticles were used in the qualitative assessment of C6 cell labeling via light microscopy. The influence of the transfection agent poly-L-lysine on cellular uptake was examined. The quantification process was performed by relaxometry analysis in $T_{1}$ and $T_{2}$ weighted phantom images. Results: Light microscopy revealed that the aminosilane-coated magnetic nanoparticles alone or complexed with poly-L-lysine showed higher cellular uptake than did the uncoated magnetic particles. The relaxivities of the aminosilane-coated magnetic nanoparticles with a hydrodynamic diameter of $50 \mathrm{~nm}$ to a 3-T field were $r_{1}=(6.1 \pm 0.3) \times 10^{-5} \mathrm{~ms}^{-1} \mathrm{~mL} / \mu \mathrm{g}$, $r_{2}=(5.3 \pm 0.1) \times 10^{-4} \mathrm{~ms}^{-1} \mathrm{~mL} / \mu \mathrm{g}$, with a ratio of $r_{2} / r_{1} \cong 9$. The iron uptake in the cells was calculated by analyzing the relaxation rates $\left(R_{1}\right.$ and $\mathrm{R}_{2}$ ) using a mathematical relationship. Conclusions: $\mathrm{C} 6$ glioma cells have a high uptake efficiency for aminosilane-coated magnetic nanoparticles complexed with the transfection agent poly-L-lysine. The large ratio $r_{2} / r_{1} \cong 9$ indicates that these magnetic nanoparticles are ideal for quantification by magnetic resonance imaging with $\mathrm{T}_{2}$ weighted imaging techniques.
\end{abstract}

Keywords: Glioma; Cell line, tumor; Nanoparticles; Magnetic resonance imaging

\section{RESUMO}

Objetivo: Avaliar a marcação intracelular e o processo de quantificação por imagem por ressonância magnética usando nanopartículas magnéticas à base de óxido de ferro recobertas com materiais biocompatíveis em células da linhagem de glioma de rato C6 em experimentos in vitro. Esses métodos visam orientar ensaios futuros de indução de tumor in vivo, bem como possíveis aplicações da técnica de magneto-hipertermia. Métodos: $\mathrm{Na}$ avaliação qualitativa da marcação de células $\mathrm{C6}$, realizada mediante microscopia óptica comum, foram utilizadas nanopartículas magnéticas recobertas com aminosilana, dextrana, álcool polivinílico e amido. A influência do agente de transfecção poly-L-lisine na captação celular foi analisada. 0 processo de quantificação foi realizado mediante a análise de relaxometria em imagens ponderadas em $\mathrm{T}_{1}$ e $\mathrm{T}_{2}$ do phantom. Resultados: A avaliação por microscopia óptica comum mostrou que nanopartículas magnéticas recobertas com aminosilana complexadas e não complexadas com poly-L-lisine apresentam melhor captação pelas células. As relaxatividades de nanopartículas magnéticas recobertas com aminosilana com diâmetro hidrodinâmico de $50 \mathrm{~nm}$ para um campo de $3 \mathrm{~T}$ foram: $r_{1}=(6,1 \pm 0,3) \times 10^{-5} \mathrm{~ms}^{-1} \mathrm{~mL} / \mu \mathrm{g}$, $r_{2}=(5,3 \pm 0,1) \times 10^{-4} \mathrm{~ms}^{-1} \mathrm{~mL} / \mu \mathrm{g}$; com uma razão de $r_{2} / r_{1} \cong 9$. 0

\footnotetext{
Study carried out at the Instituto Israelita de Ensino e Pesquisa Albert Einstein, Hospital Israelita Albert Einstein - HIAE, São Paulo (SP), Brazil.

Instituto do Cérebro - InCe, Hospital Israelita Albert Einstein - HIAE, São Paulo (SP), Brazil.

${ }^{2}$ Instituto do Cérebro - InCe, Hospital Israelita Albert Einstein - HIAE, São Paulo (SP), Brazil; Faculdade de Enfermagem do Hospital Israelita Albert Einstein - HIAE, São Paulo (SP), Brazil.

${ }^{3}$ Department of Diagnostic Imaging and Instituto do Cérebro - InCe, Hospital Israelita Albert Einstein - HIAE, São Paulo (SP), Brazil.

Corresponding author: Javier Bustamante Mamani - Instituto do Cérebro - Hospital Israelita Albert Einstein - Avenida Albert Einstein, $627 / 701$ - Morumbi - Zip code: 05651-901 - São Paulo (SP), Brazil Phone: (55 11) 2151-2044 - E-mail: javierbm@einstein.br

Received on: Mar 30, 2012 - Accepted on: May 25, 2012

Conflicts of interest: none.
} 
ferro captado pelas células foi calculado pela análise das taxas de relaxação $\left(R_{1}\right.$ e $\left.R_{2}\right)$ mediante relação matemática. Conclusões: Linhagem de células C6 marcadas com nanopartículas magnéticas revestidas com aminosilana e complexadas com 0 agente de transfecção poly-L-lisine tem uma alta eficiência de captação das nanopartículas magnéticas. A grande razão $r_{2} / r_{1} \cong 9$ determina que essas nanopartículas magnéticas sejam ideais para estudar 0 processo de quantificação por imagem por ressonância magnética com técnicas de imagem ponderadas em $\mathrm{T}_{2}$.

Descritores: Glioma; Linhagem celular tumoral; Nanopartículas; Imagem por ressonância magnética

\section{INTRODUCTION}

Several approaches for the use of contrast agents in magnetic resonance imaging (MRI) to label cells have been developed for experimental and clinical applications. The development of methods for in vivo cell detection and the differentiation of cells labeled with a contrast agent that is composed of magnetic nanoparticles (MNPs) that are based on iron oxide have made MRI an essential technique in the monitoring of cells labeled with implanted MNPs. The MRI technique is advantageous because it is non-invasive and does not cause ionizing radiation damage, making it ideal for studies of cell labeling by analyzing the characteristic relaxation times, i.e., the longitudinal relaxation time $\left(\mathrm{T}_{1}\right)$ and the transverse relaxation time $\left(\mathrm{T}_{2}\right)$.

Iron oxide nanoparticles coated with biocompatible materials are developed to examine the reticuloendothelial system $(\mathrm{RES})^{(1)}$, perform MRI lymphography ${ }^{(2)}$ and MRI of gene expression ${ }^{(3)}$, and monitor in vivo cell migration $^{(4-6)}$, among other applications. These applications intrinsically depend on an efficient MNP uptake by the cell types of interest. The internalization or uptake of MNPs occurs by pinocytosis, a mechanism by which nanoparticles are brought into the cells ${ }^{(7)}$.

There are several MNPs used for cell labeling that are coated with different biocompatible materials, such as aminosilane, dextran, polyvinyl alcohol (PVA), and starch, among others. Uptake efficiency is low in certain types of cells; therefore, a high MNP concentration must be used for labeling, with long incubation times. However, there are some alternatives, such as the use of transfection agents, for increasing the MNP uptake efficiency.

Cell labeling with MNPs for in vivo experiments can be performed in the following three ways: (i) intravenous MNP administration and their subsequent uptake by the target cells, (ii) direct
MNP administration in the target tissues, and (iii) administration of cells labeled in vitro for subsequent implantation in the target sites.

One technique that involves the administration of MNP-labeled cells is magnetic hyperthermia ${ }^{(8)}$ for in vivo studies in animal models (induction of tumor tissue). Tumor induction after the administration of previously labeled cells enables MRI monitoring of tumor development in vivo. Induced tumor tissue labeled with MNPs can be lysed through magnetic hyperthermia, which is based on the increased temperature of the tumor tissue when the labeled cells are subjected to an AC magnetic field.

After cells are labeled by the methods described above, the iron load per unit of tissue volume or per cell must be quantified, in addition to monitoring the labeled cell. One technique that allows such monitoring and quantification is $\mathrm{MRI}^{(9,10)}$.

The understanding and control of cell labeling using MNPs are essential for these applications. MNP intracellular labeling has been shown to be an adequate system for in vivo identification and monitoring by MRI. This labeling can be performed in vivo or in vitro (i.e., stem cells cultivated and labeled before in vivo implantation) by cell internalization pathways ${ }^{(11)}$.

This work aimed to optimize the labeling of rat C6 glioma cells with magnetite $\left(\mathrm{Fe}_{3} \mathrm{O}_{4}\right)$ and $\mathrm{Fe}_{3} \mathrm{O}_{4} \mathrm{MNPs}$ coated with aminosilane, dextran, PVA, or starch. These four types of particles are also complexed with poly-L-lysine (PLL). After the optimal type of MNP (i.e., highest cellular MNP uptake) was determined, quantification was performed by MRI via the study of relaxometry in a 3-T MRI scanner.

\section{OBJECTIVE}

To study intracellular labeling and MRI quantification using iron oxide MNPs coated with biocompatible materials in rat $\mathrm{C} 6$ glioma cells to further research on the tumor induction process in vivo, as well as the application of the magnetic hyperthermia technique.

\section{METHODS}

\section{Iron oxide MNPs}

The MNPs used in this study consist of iron oxide superparamagnetic particles coated with aminosilane, dextran, PVA, or starch (Chemicell GmbH, Berlin, Germany). These MNPs have a hydrodynamic diameter 
of $50 \mathrm{~nm}$. The crystalline phase of the superparamagnetic core corresponds to $\mathrm{Fe}_{3} \mathrm{O}_{4}$. The colloidal suspension concentration corresponds to $50 \mathrm{mgFe} / \mathrm{mL}$ that is dispersible in double distilled water.

\section{Cell culture}

The C6 cell line was acquired from the Rio de Janeiro Cell Bank (Banco de Células do Rio de Janeiro - BCRJ), which is managed by the Paul Ehrlich Technical and Scientific Association (Associação Técnico-Científica Paul Ehrlich - APABCAM). The cells were plated at a density of $10^{7}$ cells per $75 \mathrm{~cm}^{2}$ in culture flasks (Corning, USA) using Dulbecco's modified Eagle's medium $\left(\mathrm{GIBCO}^{\circledast}\right.$ Invitrogen Corporation, CA, USA) supplemented with $10 \%$ fetal bovine serum (FBS) (GIBCO ${ }^{\circledR}$ Invitrogen Corporation, CA, USA), $1 \%$ penicillin-streptomycin $\left(\mathrm{GIBCO}^{\circledR}\right.$ Invitrogen Corporation, CA, USA), and 1\% L-glutamine $\left(\mathrm{GIBCO}^{\circledR}\right.$ Invitrogen Corporation, CA, USA). The cells were cultured at $37^{\circ} \mathrm{C}$ with $5 \% \mathrm{CO}_{2}$. After reaching $70 \%$ cell confluence, adherent $\mathrm{C} 6$ cells were collected with the use of $0.25 \%$ trypsin $\left(\mathrm{GIBCO}^{\circledR}\right.$ Invitrogen Corporation, CA, USA) at $37^{\circ} \mathrm{C}$ for five minutes.

\section{Cell labeling}

C6 cells at 70-80\% confluence were incubated overnight (approximately 12 hours at $37^{\circ} \mathrm{C}, 5 \% \mathrm{CO}_{2}$ ) in $20 \mathrm{~mL}$ of culture medium plus MNPs at concentrations of 0, 5, 10, 50 and $100 \mu \mathrm{g} \mathrm{Fe} / \mathrm{mL}$. After incubation, the supernatant was removed, and the C6 cells were washed twice with FBS to remove extracellular MNPs. The C6 cells labeled with MNPs were collected with trypsin to remove adherent cells and were manually counted in a Neubauer chamber.

\section{Intracellular distribution of MNPs in $\mathbf{C} 6$ cells}

MNP internalization by C6 cells was assessed qualitatively by the distribution and intracellular location of MNPs using Prussian blue staining (Prussian Blue Kit, BioPAL Inc., Worcester, MA) and analysis using a compound light microscope (CLM). This cytochemical test with labeled C6 cells was performed for a period of two minutes.

These properties were evaluated for concentrations of 10 and $500 \mu \mathrm{g} \mathrm{Fe} / \mathrm{mL}$ in the presence and absence of the transfection agent PLL (Sigma-Aldrich Chemie $\mathrm{GmbH}$, Germany) at a concentration of $1.5 \mu \mathrm{g} / \mathrm{mL}$.

\section{In vitro assessment using MRI}

\section{Phantom design}

A phantom consisting of a set of $250-\mu \mathrm{L}$ Eppendorf tubes filled with pellets of an equal number of cells $\left(5 \times 10^{6}\right)$ that were incubated with concentrations of $0,5,10,50$ and $100 \mu \mathrm{g} \mathrm{Fe} / \mathrm{mL}$ was prepared. In Eppendorf tubes, the pellets were mixed with $150 \mu \mathrm{L}$ $1 \%$ agarose (Sigma-Aldrich Chemie $\mathrm{GmbH}$, Germany). After the agarose cooled and solidified, MRI analysis was performed. To compare the iron uptake of the C6 cells, an Eppendorf tube containing the contrast agent at a concentration of $50 \mu \mathrm{gFe} / \mathrm{mL}$ was added to each phantom.

\section{Imaging sequence}

The relaxometry characteristics of the phantom were evaluated with a whole-body 3-T MRI scanner with a wrist coil (Magnetom Vision, Siemens, Germany), using $\mathrm{T}_{1}$ - and $\mathrm{T}_{2}$-weighted imaging sequences. The parameters used in the imaging sequences were published by Gamarra et al. ${ }^{(12)}$. The MNP relaxation times were measured for different samples. For the measurements of $\mathrm{T}_{2}$ relaxation times, the multicontrast turbo-spin-echo (se_mc) sequence was used. The $\mathrm{T}_{2}$ relaxation time of each nanoparticle sample was obtained by adjusting the decay curve with a monoexponential linear algorithm, Intensity $=C_{1} \exp \left(-T E / T_{2}\right)$. For the $\mathrm{T}_{1}$ measurements, the multiple spin-echo (SE) sequence was used. The equation of signal intensity for $\mathrm{T}_{1}$ measurements is Intensity $=C_{2}\left(1-\exp \left(T R / T_{1}\right)\right)$, where $\mathrm{TE}$ is the echo time, TR is the repetition time, and $\mathrm{C}_{1}$ and $\mathrm{C}_{2}$ are constants. The MR signal intensities from different areas were determined by measurements of the regions of interest.

\section{MRI quantification of MNPs internalized in $\mathbf{C 6}$ cells}

The quantification of MNPs in labeled C6 cells was performed by relaxometry. The relaxation rates $\left(\mathrm{R}_{1}=1 / \mathrm{T}_{1}\right.$ and $\left.\mathrm{R}_{2}=1 / \mathrm{T}_{2}\right)$ were determined in $\mathrm{ms}^{-1}$ for subsequent correlation with the MNP concentration in the cells and their relaxivities $r_{1}$ and $r_{2}\left(\right.$ in $\mathrm{ms}^{-1} \mathrm{~mL} / \mu \mathrm{g}$ ). The relaxation rate can thus be expressed by ${ }^{(13)}$

$$
\frac{1}{T_{1,2}^{\text {Sample }}}=\left(\frac{1}{T_{1,2}^{\text {Cell Suspension }}}\right)_{[F e]=0}+[\mathrm{Fe}] \times r_{1,2}
$$

The iron concentration in the different samples was determined using the reference values of the relaxivity and the relaxation time of the unlabeled cell suspension $([\mathrm{Fe}]=0)$. 


\section{RESULTS}

\section{Qualitative analysis of cell labeling}

MNPs coated with aminosilane, dextran, PVA, or starch were used to label C6 cells. The concentrations used for incubation were 10 and $500 \mu \mathrm{g} \mathrm{Fe} / \mathrm{mL}$. The cells were incubated in the presence or absence of the transfection agent PLL. The qualitative analysis of the Prussian blue staining is presented in figure 1 .

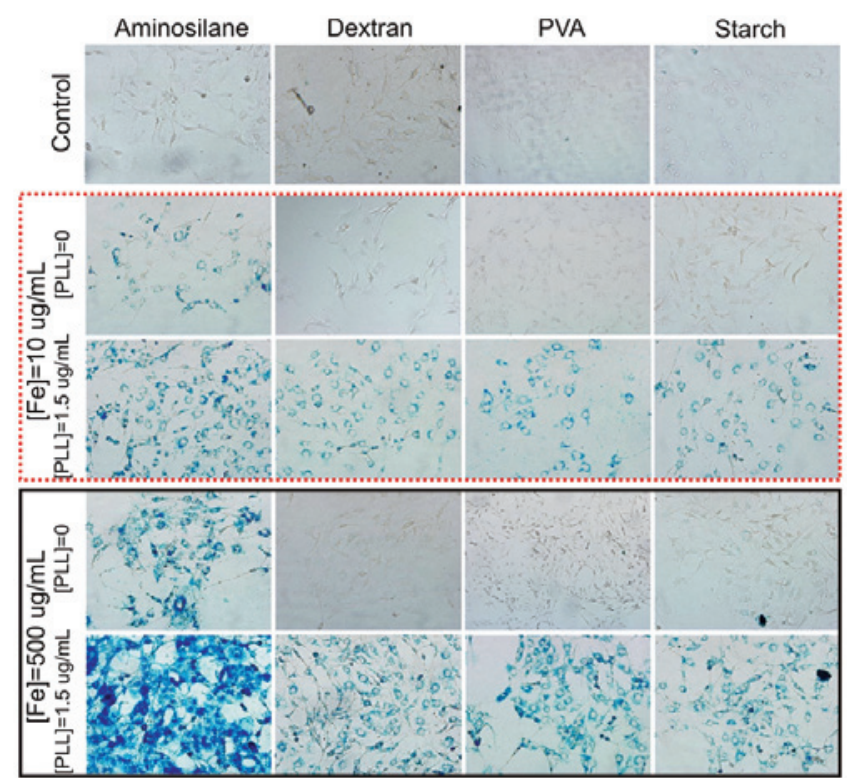

Figure 1. Cytochemical assay by the Prussian blue method highlights $\mathrm{C} 6$ cells labeled with varying concentrations of magnetic nanoparticles coated with aminosilane, dextran, polyvinyl alcohol, or starch using the transfection agent PLL

\section{Relaxivity determination using MRI}

The relaxivities $r_{1}$ and $r_{2}$ in $\mathrm{ms}^{-1} \mathrm{~mL} / \mu \mathrm{g}$ (Table 1) were calculated by analyzing the results of the linear leastsquares adjustment of the slope of the graph of the contrast agent dispersed in water (5 to $100 \mu \mathrm{gFe} / \mathrm{mL}$ ) versus the relaxation rates $R_{1}=1 / T_{1}$ and $R_{2}=1 / T_{2}$. In this

Table 1. Parameters obtained from the analysis of the relaxation curves at different iron concentrations. The number of labeled cells is the same at each concentration $\left(5 \times 10^{6}\right.$ cells $)$ after the incubation period

\begin{tabular}{|c|c|c|c|c|c|c|}
\hline \multirow[b]{2}{*}{$\begin{array}{l}{[\mathrm{Fe}]} \\
(\mu \mathrm{g} / \mathrm{mL})\end{array}$} & \multicolumn{3}{|c|}{$r_{1}=(6.1 \pm 0.3) \times 10^{-5} \mathrm{~ms}^{-1} \mathrm{~mL} / \mu \mathrm{g}$} & \multicolumn{3}{|c|}{$r_{2}=(5.3 \pm 0.1) \times 10^{-4} \mathrm{~ms}^{-1} \mathrm{~mL} / \mu \mathrm{g}$} \\
\hline & $\begin{array}{c}\mathrm{T}_{1} \\
\text { (ms) }\end{array}$ & 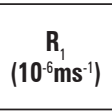 & $\begin{array}{c}{[\mathrm{Fe}]} \\
\text { uptake } \\
(\mu \mathrm{g} / \mathrm{mL})\end{array}$ & $\begin{array}{c}\mathrm{T}_{2} \\
\text { (ms) }\end{array}$ & $\begin{array}{c}\mathbf{R}_{2} \\
\left(10^{-5} \mathrm{~ms}^{-1}\right)\end{array}$ & $\begin{array}{c}{[\mathrm{Fe}]} \\
\text { uptake } \\
(\mu \mathrm{g} / \mathrm{mL}) \\
\end{array}$ \\
\hline 0 & $2,554 \pm 21$ & $392 \pm 3$ & - & $544 \pm 22$ & $184 \pm 7$ & - \\
\hline 5 & $2,455 \pm 17$ & $407 \pm 3$ & $0.47 \pm 0.04$ & $232 \pm 5$ & $431 \pm 9$ & $3.2 \pm 0.3$ \\
\hline 10 & $2,364 \pm 19$ & $423 \pm 3$ & $0.93 \pm 0.10$ & $212 \pm 4$ & $472 \pm 9$ & $3.7 \pm 0.4$ \\
\hline 50 & $2,360 \pm 23$ & $424 \pm 4$ & $0.95 \pm 0.12$ & $182 \pm 3$ & $550 \pm 9$ & $4.7 \pm 0.5$ \\
\hline 100 & $1,978 \pm 3$ & $506 \pm 1$ & $3.37 \pm 0.28$ & $99 \pm 3$ & $1,010 \pm 31$ & $10.6 \pm 1.2$ \\
\hline
\end{tabular}

adjustment, the slope corresponds to the inverse values of the relaxivities, $1 / \mathrm{r}_{1}$ and $1 / \mathrm{r}_{2}$ (Figure 2).

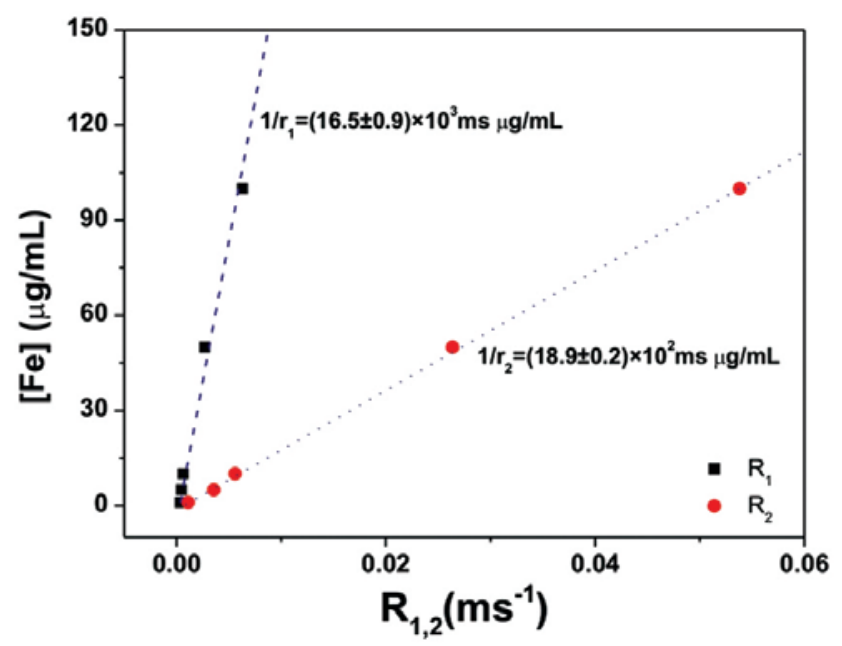

Figure 2. Concentration of Fe versus the relaxation rates $R_{1}$ and $R_{2}$. The values of $1 / r_{1}$ and $1 / r_{2}$ resulting from the fit to the experimental data are shown for each adjusted curve

\section{In vitro quantification using MRI}

The $T_{1}$ and $T_{2}$ proton relaxation times of cells labeled with different MNP concentrations were obtained by MRI analysis. The intensity curves associated with the contrast of the characteristic $\mathrm{T}_{1}$ and $\mathrm{T}_{2}$ images are shown in figures 3 and 4 , respectively. The $T_{1}$ and $T_{2}$ values obtained from fitting the experimental data to

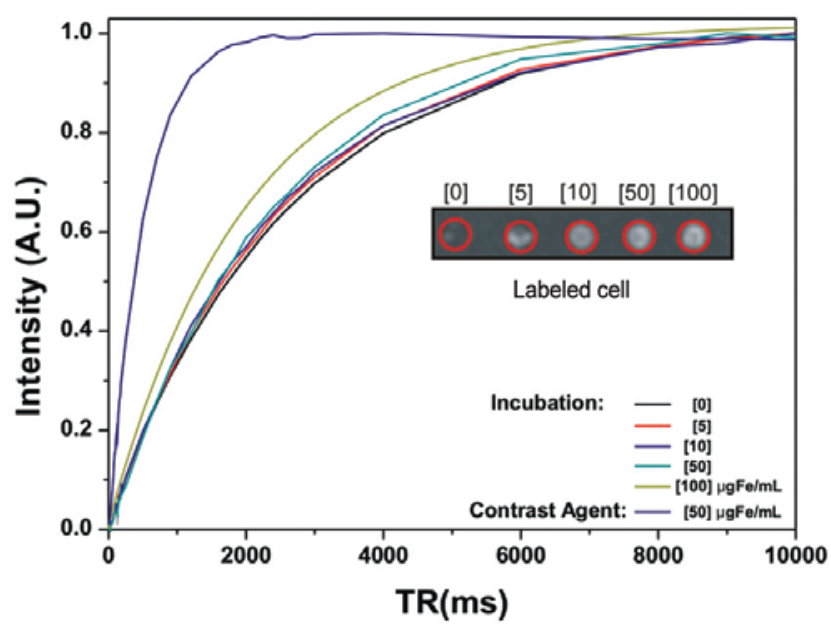

Figure 3. Intensity curves versus the TR representative of the longitudinal relaxation obtained from the analysis of the phantom magnetic resonance images. The $T$ times of each curve were calculated from the fit to the experimental data (values in table 1). The inset shows the $T_{1}$-weighted phantom magnetic resonance image obtained by the multiple SE sequence at $T R=500 \mathrm{~ms}$ and $T E=8.5 \mathrm{~ms}$. The intensity curve of the contrast agent at a concentration of $50 \mu \mathrm{g} \mathrm{Fe} / \mathrm{mL}$ is higher than the intensity of the labeled cells at the same TR 


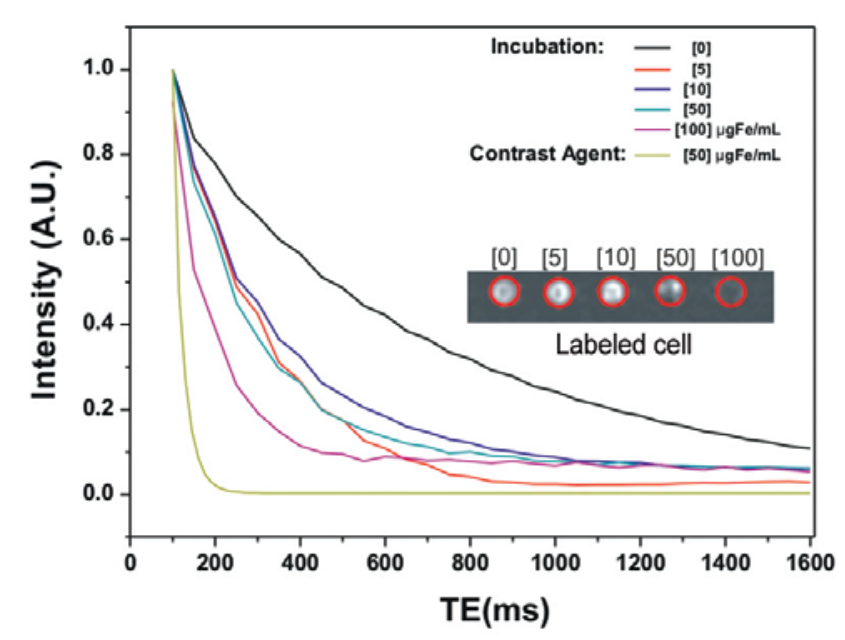

Figure 4. Intensity curves versus the TE representative of the transverse relaxation obtained from the analysis of the phantom magnetic resonance images. The $T_{2}$ times of each curve were calculated by the fit to the experimental data (values in table 1). The inset shows the $\mathrm{T}_{2}$-weighted phantom magnetic resonance image obtained by the se mc sequence at $T R=3,000 \mathrm{~ms}$ and $T E=26.2 \mathrm{~ms}$. The intensity curve of the contrast agent at a concentration of $50 \mu \mathrm{g} \mathrm{Fe} / \mathrm{mL}$ is lower than the intensity of the labeled cells at the same TE

the characteristic functions and the relaxation rates $R_{1}$ and $R_{2}$ are shown in table 1 .

Table 1 contains a summary of the phantom MRI analysis parameters used in this study, including the relaxation times $\left(\mathrm{T}_{1}\right.$ and $\left.\mathrm{T}_{2}\right)$, relaxation rates $\left(\mathrm{R}_{1}\right.$ and $\left.\mathrm{R}_{2}\right)$, the relaxivities $\left(r_{1}\right.$ and $\left.r_{2}\right)$, and the iron concentrations taken up by the cells $\left([\mathrm{Fe}]_{\text {uptake }}\right)$.

\section{DISCUSSION}

The images obtained through CLM (Figure 1) show that MNPs coated with dextran, PVA, or starch were not internalized by the cells when incubated at high $(500 \mu \mathrm{g} \mathrm{Fe} / \mathrm{mL})$ or low $(10 \mu \mathrm{g} \mathrm{Fe} / \mathrm{mL})$ concentrations. However, when these MNPs were complexed with PLL, the cells internalized MNPs, albeit with a low uptake efficiency. In the case of aminosilane-coated MNPs, the cells internalized MNPs even without the use of PLL. An increased uptake was observed in comparison with other MNPs. PLL complexing decreased the internalization of aminosilane-coated MNP, although it increased the efficiency of C6 cell labeling.

MRI quantification of iron loading by $\mathrm{C} 6$ cells was only performed with MNP coated with aminosilane and complexed with PLL due to the high labeling efficiency of this MNP preparation compared with the other MNPs analyzed.

The MRI relaxometry analysis yielded the following values for $r_{1}$ and $r_{2}$, calculated from the slopes of the curves in figure 2: $\mathrm{r}_{1}=(6.1 \pm 0.3) \times 10^{-5} \mathrm{~ms}^{-1} \mathrm{~mL} / \mu \mathrm{g}$, $\mathrm{r}_{2}=(5.3 \pm 0.1) \times 10^{-4} \mathrm{~ms}^{-1} \mathrm{~mL} / \mu \mathrm{g}$. The $\mathrm{r}_{1}$ relaxivity was smaller than $r_{2}$, indicating that the distance between the water molecules and cores of the coated MNPs was small. A slightly higher relaxivity could be the result of aggregated MNPs, which generate a slightly larger local magnetic field fluctuation than do dispersed MNPs.

The $r_{2}$ relaxivity was high, indicating that $T_{2}$ was much more influenced by the nanoparticle coating than was $\mathrm{T}_{1}$; this finding was expected, considering that $\mathrm{T}_{2}$ is more sensitive to magnetic inhomogeneity than is $T_{1}$. To achieve the maximum effect of the contrast agent in $\mathrm{T}_{2}$, the MNPs should be coated with layers that are as thin as possible because the interaction between magnetic particles and water molecules depends on the distance between them.

In MRI, the relaxation times can be manipulated with a contrast agent, for example, $\mathrm{T}_{1}$ with gadolinium or manganese and $\mathrm{T}_{2}$ with iron oxide particles. The efficiency of the MRI contrast agent is commonly evaluated in terms of its $r_{1}$ and $r_{2}$ relaxivity. For a $T_{2}$ contrast agent, a higher $r_{1} / r_{2}$ ratio indicates a better contrast efficiency ${ }^{(14)}$. Thus, with its ratio of $r_{2} / r_{1} \cong 9$, aminosilane-coated MNP is a high-efficiency $\mathrm{T}_{2}$ contrast agent in 3-T fields.

The insets in figures 3 and 4 show $\mathrm{T}_{1}$ - and $\mathrm{T}_{2}$ weighted images, respectively. The $\mathrm{T}_{1}$-weighted image obtained for different concentrations shows a signal intensity increase with increasing MNP concentrations taken up by C6 cells due to the shortening of $\mathrm{T}_{1}$, as shown in the curves of figure 3 . In the case of $T_{2}$, the opposite trend occurs, as shown in figure 4 , because the increase in MNP uptake by the C6 cells was equal to the decrease in signal intensity.

The MRI assessment of the MNP uptake by C6 cells was more evident in the analysis of $\mathrm{T}_{2}$-weighted images due to the coating of MNPs with aminosilane, which acted as a high-efficiency contrast agent in $\mathrm{T}_{2}$. Therefore, for this contrast agent, the determination of iron uptake by cells should be performed by analyzing $\mathrm{T}_{2}$-weighted images ${ }^{(15)}$. Conversely, the values for iron uptake by cells analyzed in the $T_{1}$-weighted images were unreliable due to the small values of $R_{1}$ compared to $\mathrm{R}_{2}$. The iron uptake values are shown in table 1 . The iron concentrations taken up by $\mathrm{C} 6$ cells $\left([\mathrm{Fe}]_{\text {uptake }}\right)$ were calculated after the parameters $\mathrm{T}_{1}, \mathrm{~T}_{2}, \mathrm{R}_{1}, \mathrm{R}_{2}, \mathrm{r}_{1}$, and $\mathrm{r}_{2}$ were determined, as shown in table 1. When the C6 cells were incubated at a concentration of $100 \mu \mathrm{g} \mathrm{Fe} / \mathrm{mL}$, they internalized $10.6 \pm 1.2 \mu \mathrm{g} \mathrm{Fe} / \mathrm{mL}$, resulting in an iron uptake percentage of approximately $10 \%$. 


\section{CONCLUSION}

Rat C6 glioma cells efficiently internalized aminosilanecoated MNPs complexed with the transfection agent PLL. The MNPs coated with dextran, PVA, or starch, even when complexed with PLL, showed little uptake by C6 cells. The relaxivity values of the aminosilanecoated MNPs determined in a 3-T magnetic field were $\mathrm{r}_{1}=(6.1 \pm 0.3) \times 10^{-5} \mathrm{~ms}^{-1} \mathrm{~mL} / \mu \mathrm{g}$ and $\mathrm{r}_{2}=(5.3 \pm 0.1) \times$ $10^{-4} \mathrm{~ms}^{-1} \mathrm{~mL} / \mu \mathrm{g}$. The large ratio $r_{2} / r_{1} \cong 9$ indicates that these MNPs are ideal for quantitative $\mathrm{T}_{2}$-weighted MRI studies.

A standardized assay for rat C6 glioma cell line labeling and in vitro quantification by MRI were shown to be efficient tools for future studies toward the implementation of magnetic hyperthermia techniques.

\section{ACKNOWLEDGEMENTS}

This study was supported by the Instituto Israelita de Ensino e Pesquisa Albert Einstein - IIEPAE, Conselho Nacional de Desenvolvimento Científico e Tecnológico - CNPq, Financiadora de Estudos e Projetos - FINEP, Coordenação de Aperfeiçoamento de Pessoal de Nível Superior - CAPES, and the Fundação de Amparo à Pesquisa do Estado de São Paulo - FAPESP.

\section{REFERENCES}

1. Oswald P, Clement O, Chambon C, Schouman-Claeys E, Frija G. Liver positive enhancement after injection of superparamagnetic nanoparticles: respective role of circulating and uptaken particles. Magn Reson Imaging. 1997; 15(9):1025-31.

2. Réty F, Clément 0 , Siauve $N$, Cuénod $C A$, Carnot $F$, Sich $M$, et al. MR lymphography using iron oxide nanoparticles in rats: pharmacokinetics in the lymphatic system after intravenous injection. J Magn Reson Imaging. 2000; 12(5):734-9.

3. Weissleder R, Moore A, Mahmood U, Bhorade R, Benveniste H, Chiocca EA, et al. In vivo magnetic resonance imaging of transgene expression. Nat Med. 2000;6(3):351-5.

4. Lewin M, Carlesso N, Tung CH, Tang XW, Cory D, Scadden DT, et al. Tat peptide-derivatized magnetic nanoparticles allow in vivo tracking and recovery of progenitor cells. Nat Biotechnol. 2000;18(4):410-4.

5. Bulte JW, Zhang S, van Gelderen P, Herynek V, Jordan EK, Duncan ID, et al. Neurotransplantation of magnetically labeled oligodendrocyte progenitors: magnetic resonance tracking of cell migration and myelination. Proc Natl Acad Sci USA. 1999;96(26):15256-61.

6. Bulte JW, Douglas T, Witwer B, Zhang SC, Strable E, Lewis BK, et al. Magnetodendrimers allow endosomal magnetic labeling and in vivo tracking of stem cells. Nat Biotechnol. 2001;19(12):1141-7.

7. Conner SD, Schmid SL. Regulated portals of entry into the cell. Nature. 2003; 422(6927):37-44.

8. Silva AC, Oliveira TR, Mamani JB, Malheiros SM, Malavolta L, Pavon LF, et al. Application of hyperthermia induced by superparamagnetic iron oxide nanoparticles in glioma treatment. Int J Nanomedicine. 2011;6:591-603.

9. Liu W, Frank JA. Detection and quantification of magnetically labeled cells by cellular MRI. Eur J Radiol. 2009;70(2):258-64.

10. Rad AM, Arbab AS, Iskander AS, Jiang Q, Soltanian-Zadeh H. Quantification of superparamagnetic iron oxide (SPIO)-labeled cells using MRI. J Magn Reson Imaging. 2007;26(2):366-74

11. Modo M, Hoehn M, Bulte JW. Cellular MR imaging. Mol Imaging. 2005; 4(3):143-64.

12. Gamarra LF, Amaro E Jr, Alves S, Soga D, Pontuschka WM, Mamani JB, et al Characterization of the biocompatible magnetic colloid on the basis of Fe304 nanoparticles coated with dextran, used as contrast agent in magnetic resonance imaging. J Nanosci Nanotechnol. 2010;10(7):4145-53.

13. Boutry S, Forge D, Burtea C, Mahieu I, Murariu O, Laurent S, et al. How to quantify iron in an aqueous or biological matrix: a technical note. Contrast Media Mol Imaging. 2009;4(6):299-304

14. Oin J, Laurent S, Jo YS, Roch A, Mikhaylova M, Bhujwalla ZM, et al. A highperformance magnetic resonance imaging T2 contrast agent. Adv Mater. 2007;19(14):1874-8.

15. Bos $C$, Delmas $Y$, Desmoulière $A$, Solanilla $A$, Hauger 0 , Grosset $C$, et al. In vivo MR imaging of intravascularly injected magnetically labeled mesenchymal stem cells in rat kidney and liver. Radiology. 2004;233(3):781-9. 